\title{
Allies will expose Iraq's weapons, says Blix
}

Declan Butler, Paris

Hans Blix, the chief weapons inspector for the United Nations (UN), last week admitted that it will be the US-led coalition invading Iraq, and not the UN, that will take the lead in tracking down and interrogating Iraqi scientists involved in the development of any chemical, biological or nuclear weapons there.

Speaking in Stockholm at a seminar on postwar Iraq, Blix said that the coalition would stand a better chance of finding weapons of mass destruction (WMD) than

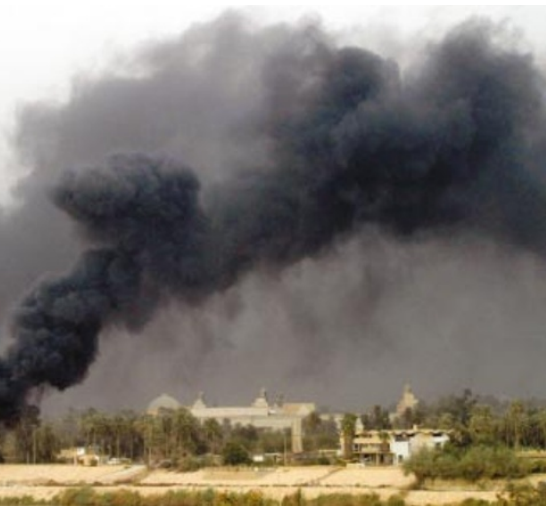

The US hoped to track down weapons scientists as its troops moved into Baghdad this week. his inspectors had done, because Iraqi scientists would be more cooperative once Saddam Hussein's regime had been overthrown. "Clearly, the allies are likely to have more success than we did, as people will be less fearful of speaking up as the regime disintegrates," says Ewen Buchanan, a spokesman for UNMOVIC, the United Nations Monitoring, Verification and Inspection Commission.

The coalition forces already have Iraqi weapons scientists in their sights. "Those weapons will be identified, found, along with the people who have produced them and who guard them," General Tommy Franks, head of US Central Command, told a press briefing in Doha, Qatar, late last month. A Pentagon spokesperson confirmed that "interviews with key Iraqi scientists, technicians and administrators associated with WMD programmes may be our most powerful tools for unearthing Iraq's hidden programmes".

The United States is putting together its own 'mobile inspection teams', drawn from the armed services, Department of Energy laboratories and private defence contractors, to search for weapons and weapons scientists.

Nations that are not part of the invasion force will probably want independent UN verification of any US claims that such weapons exist or that Iraq has the capacity to produce them. But scientists are likely to be interrogated during the conflict, and before a UN presence in Iraq has been re-established.

Unfettered access to Iraqi scientists was demanded by the UN Security Council resolution on Iraq, passed last November. But UN inspectors were able to speak privately with only 14 of the 500 listed for interview.

The US push into Baghdad this week takes its troops to where biological or chemical weapons facilities, and the scientists involved in their development, are likely to be found. The scientists, however, may have less information about actual weapons stockpiles than do military personnel, and the top US priority will be to find and secure these stockpiles. As of 7 April, no discovery of weapons of mass destruction had been confirmed.

After the war, information from the weapons scientists will be critical to any understanding of how, or if, Iraq has developed weapons of mass destruction since the first Gulf War, and whether it has shared the technology with groups outside the country.

Kofi Annan, the UN secretary general, said on 24 March that only UN inspectors could determine Iraq's weapons status, and that he expected inspections to resume after the conflict.

\section{Japan aims to let industry compete for grant money}

Keiko Kandachi, Tokyo

Japanese academics are nervously eyeing a government plan that would open up the country's main research programmes to industrial participation for the first time.

University researchers worry that the plan, which is being considered by Japan's highest scientific decision-making body, the Council for Science and Technology Policy (CSTP), could lead to a major transfer of resources from universities to more applied research projects in industrial labs.

As the moment, industrial researchers cannot apply for Japan’s largest competitive grant programme, which distributed $¥ 143$ billion (US\$1.2 billion) last year. The 'grantsin-aid' programme, which provides about half of all the competitive research funding available in Japan, is vital to the country's basic research. But Hiroo Imura, chairman of the CSTP's grant-reform committee, says that all funding sources should be open to all researchers, regardless of affiliation.

Japan's prime minister, Junichiro Koizumi, said at the CSTP's plenary session on 28 March that the 'grants-in-aid' programme should be "fundamentally revamped", according to a subsequent briefing by government officials. The CSTP committee will spell out details of the revamp in a report early next month.

Advocates of the plan point out that US corporations have benefited for years from government research grants. Statistics from the US National Science Foundation show that $40 \%$ of all US federal grant money for research and development went to industry in 2001, compared with only $10 \%$ in Japan.

The CSTP report is expected to argue that the change is needed to enhance the diversity of grantees and to encourage competition between academic and industrial researchers, in line with university reforms (see Nature 419 , 875-876; 2002).

But Takahisa Onishi, an official at the education ministry who deals with university grants, says the real motive is to help Japanese companies that have been forced by economic recession to slash their own research budgets.

The universities are furious at the plan, but may be powerless to stop it. Tadamitsu Kishimoto, president of Osaka University, who serves on the CSTP committee, predicts that the change will effectively divert money into applied work with quick results, at the expense of long-term basic research.

Industrialists, unsurprisingly, are more upbeat. Ikunoshin Kato, president of Takara Bio, a Japanese biotechnology company, who is also on the CSTP committee, says: "It's not fair that we can't apply for large grants simply because we are in the private sector."

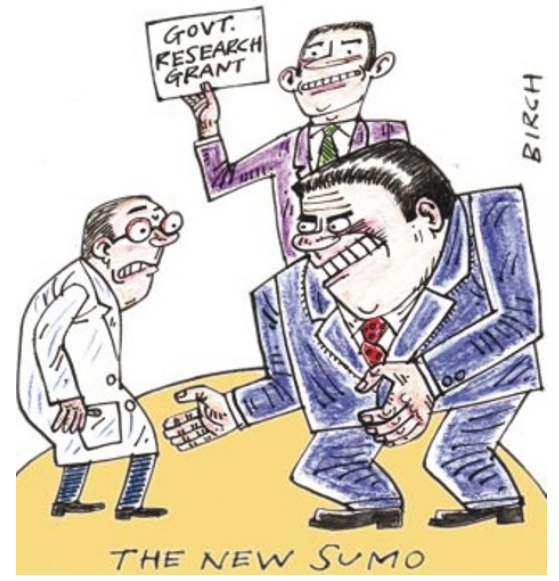

